\title{
COMPOSITIONS AND THERMO-CHEMICAL ANALYSIS OF BOVINE AND CAPRINE BONES
}

\author{
Olusola E. Ojo ${ }^{1,2, *}$, Israel O. Sekunowo ${ }^{1}$, Margaret O. Ilomuanya ${ }^{3}$, Philip O. Gbenebor ${ }^{1}$ \\ and Samson O. Adeosun ${ }^{1}$ \\ ${ }^{1}$ Department of Metallurgical \& Materials Engineering, Faculty of Engineering, \\ University of Lagos, Akoka, Lagos, Nigeria. \\ ${ }^{2}$ Projects Development and Design Department, Federal Institute of Industrial \\ Research, Cappa Bus Stop, Oshodi, Lagos, Nigeria. \\ ${ }^{3}$ Department of Pharmaceutics and Pharmaceutical Technology, Faculty of Pharmacy, \\ University of Lagos, Idi -Araba, Lagos, Nigeria. \\ *corresponding author: email: isolyet@yahoo.com \\ HTTP://DX.DOI.ORG/10.30572/2018/KJE/120305
}

\begin{abstract}
Studies have been carried out on bovine bone due to its abundance and large quantity of hydroxyapatite (HAP) in it while caprine bone has been understudied. In this study, locally sourced bovine and caprine bones were washed in distilled water, defatted at $120^{\circ} \mathrm{C}$ for $1.5 \mathrm{hr}$ in a pressure pot, ball-milled, sieved to $150 \mu \mathrm{m}$ particle size and characterised. The X-ray fluorescence (XRF) and Energy dispersive X-Ray Spectroscopy (EDS) analysis revealed calcium, phosphorus and carbon as the main components. Both bones contained carbon and oxygen due to the presence of organic collagen but the quantity in caprine bone was a bit higher as revealed by the Fourier Transform Infrared Spectroscopy (FTIR) and EDS spectra. A slight difference in thermal decomposition patterns was recorded while X-Ray diffraction analysis (XRD) revealed the presence of identical functional phases. The microstructures showed needle-like and pebble-like shapes for bovine and caprine respectively, also on visual examination of the Scanning Electron Micrograph (SEM), the bovine samples tended to have particle surface roughness more than caprine. Consequently, the chemical properties of both bone raw samples were insignificantly different from each other except for collagen composition and morphology.
\end{abstract}

KEYWORDS: Mammalian Bone, Hydroxyapatite, Collagen, Chemical analysis,

Microstructures 


\section{INTRODUCTION}

The abundant quantity and high quality of hydroxyapatite (HAP) in mammalian bones have made significant inroad in biomedical applications due to its biocompatible and noninflammatory properties. It is also non-toxic, non-immunogenic and bioactive, which make it able to form a bond with the surrounding tissue after bone grafting (Rana et al., 2017). All these properties have made HAP useful in other applications including its use as a drug carrier (Kano et al., 1994) to selectively take drugs to the diseased cells in the body, replacement of bone tissues (Tang et al., 2009), reconstruction of skull defects (Staffa, et al., 2007), tissue engineering, biosensors (Salman et al., 2008), removal of heavy metals (Reichert et al., 2008) and as an important material in artificial bone synthesis (Hirata et al., 2008) because of its chemical and mineral phase that is closely related to bones and teeth, which is the reason for it use as titanium implantation coat in the body as it enables the body system to see the implantation as a natural bone (Mohammed, 2015). Moreover, collagen, which is the organic component of the bone extracellular matrix is also an auspicious biomaterial due to its excellent biocompatibility, cell affinity and biodegradability and consequently, the composite of HAP and collagen scaffolds has been reportedly used to chemically and structurally mimic the natural bone with excellent performance (Sun et al, 2018). Thus, researchers have studied and derived HAP from different sources majorly from mammalian bones (bovine, horse and camel). Feng (2009) stated that bones consist of $\sim 60 \%$ inorganic component (HAP), $\sim 30 \%$ organic (Collagen) and $\sim 10 \%$ water. Among the natural sources that are currently being evaluated for HAP include marine sources (fish bone and fish scale), shell sources (seashell and eggshell) and mineral sources (limestone) (MohdPu'ad et al., 2019). However, fish bone and scales are not as abundant as mammalian bones. Furthermore, as revealed in the literatures, extraction of HAP from shell and limestone sources takes a longer process and use of chemicals as larger percentage of its calcium is in carbonate form and not phosphate. Pig bones can also be used as a source of HAP, but religious sentiments are often associated with it (Venkatesan and Kim, 2013). There are many natural sources that have been studied and bovine bone remains the most well-established source due to its abundance. In the Guardians, (April 08, 2018), it was stated that Lagos State (A state in Southwest Nigeria) residents consume over 8000 cows per day. Based on calculation by Omole and Ogbiye (2013), 900 tons of bone is yielded daily from slaughtered cows constituting a huge environmental pollution. This situation appears to be similar in other parts of the world. However, for sustainable development, wastes of any class must be processed for value addition (Malla et al., 2020). Caprine bone has been understudied despite it availability. Also having no religion sentiment associated with it making anything 
derived from it acceptable by the society (Ramesh et al., 2018). Giving the bovine bones more attention than the others in research domains could be misconstrued as having superior chemical properties to others. This study is carried out to examine their compositions and thermochemical properties to confirm if there are significant differences between the two bone samples.

\section{METHODOLOGY}

\subsection{Materials and Methods}

\subsubsection{Preparation of bovine and caprine bone particles}

Bovine (Bos Taurus) and caprine (Capra aegagrus hircus) femur bones used in this study were purchased at Magboro (Lat. 6.7166 N, Long. 3.4070 E) main market in Ogun State Nigeria. The bovine and caprine bones were obtained from 36 months old and 30-36 months old animals respectively. The bones were thoroughly washed to remove dirt, blood on the surfaces and soaked for $96 \mathrm{hr}$ in water to break the strongly adhering tissues, meat and other impurities. Each of the bones were mechanically broken to $4-10 \mathrm{~cm}$ length while a hammer and anvil was used to remove the marrow. This was followed by defatting of the bones in a 10- litre Quink® pressure pot into which $4 \mathrm{~L}$ of preheated water was poured and heated to $120^{\circ} \mathrm{C}$ for $1.5 \mathrm{hr}$. On cooling, the hot water with fat was poured into a sieve to collect the fat which was weighed when the water has completely drained. It was then oven dried for $8 \mathrm{hr}$ at $80^{\circ} \mathrm{C}$.

After oven drying, each of the samples were hammer milled using Broyeur Clero® model $13634,1.5 \mathrm{kV}$, France. This process facilitated the bones size reduction to less than $10 \mathrm{~mm}$. Then the bones particles were subjected to ball milling using a Faure ${ }^{\circledR}$ machine; model 28A20:92, France. The machine has a $5 \mathrm{~kg}$-ceramic of 10-20 mm diameter milling balls with a 10-litre milling barrel. Ball milling was carried out at $40 \mathrm{rpm}$ for $24 \mathrm{hr}$ followed by sieving to $150 \mu \mathrm{m}$ prior to characterisation.

\subsubsection{Chemical and Morphological characterisation}

The phase composition of the samples was performed on an EMPYERN XRD-600

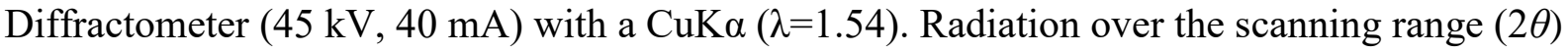
from $5^{\circ}$ to $75^{\circ}$ and a step size of $0.026^{\circ}$. To confirm the functional groups present in the raw bone samples, Agilent Technologies® (USA) FTIR analyzer was used to achieve this in the range of 4000-650 $\mathrm{cm}^{-1}$. Thermogravimetric analysis was carried out using PerkinElmer ${ }^{\circledR}$ TGA Q500 (USA) to analyze the stages in composition and thermal stability of the bovine and caprine bones. The heating started from $30^{\circ} \mathrm{C}$ to $950^{\circ} \mathrm{C}$ at $10^{\circ} \mathrm{C} /$ minute. The raw bovine and 
caprine bones samples were examined using SEM; model Phenom® Eindhoven, Netherlands. The EDS employed in this study was equipped with the SEM.

\section{RESULTS AND DISCUSSION}

\subsection{General Observations}

In the course of defatting, it was observed that the bovine and caprine bones released $6.57 \mathrm{~g}$ and $10.57 \mathrm{~g}$ of fat per kilogram of the bones respectively. This indicated that caprine bone holds more adsorbed fat than that of bovine. During milling, as shown in Fig. 1, it was observed that bovine bone samples turned grey from yellowish-white, in contrast, the caprine sample that remained unchanged in colour. This may be attributed to heat generated due to attrition during the milling process.

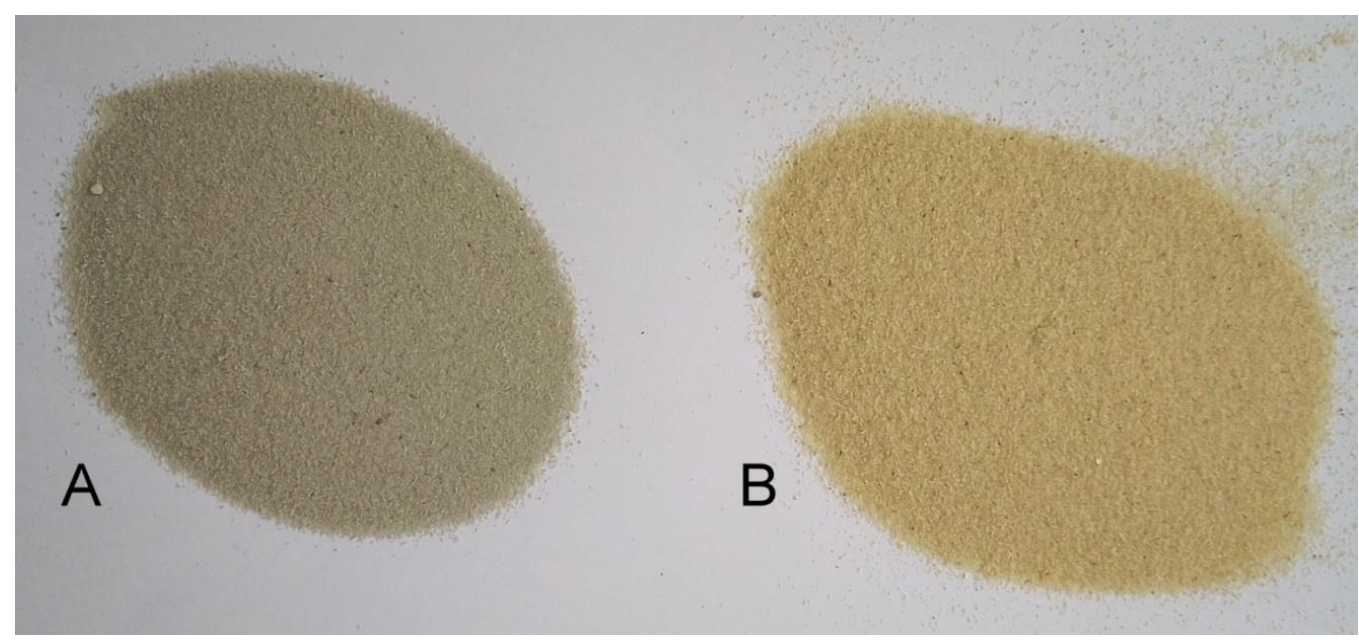

Fig. 1. Visual observation of bone powder showing the effect of milling on the colour: (A) Bovine bone changed to gray (B) Caprine bone remained unchanged.

\subsection{Thermal Decomposition Characteristics}

The mass loss curve for the two bone samples are shown in Fig. 2 with mass loss around $100^{\circ} \mathrm{C}$, which is associated with loss of moisture (Mkukuma et al., 2004). Between $200^{\circ} \mathrm{C}$ to $520^{\circ} \mathrm{C}$, both samples suffered mass loss associated with decomposition of the organic materials present in the bones. This is mainly collagen and some other organic materials like lipids, chondroitin and keratin sulphate (Manalu et al., 2015). The decomposition temperature of collagen is between these two temperature ranges. There was a slight difference in thermal decomposition patterns of the bone in the range $300^{\circ} \mathrm{C}$ to $470^{\circ} \mathrm{C}$ owing to the difference in the quantity of their organic contents. 
There was no significant mass loss in the samples beyond $600{ }^{\circ} \mathrm{C}$ as most organic substances appeared to have decomposed. Calcium carbonate decomposes above $750^{\circ} \mathrm{C}$ to give off carbon dioxide $\left(\mathrm{CO}_{2}\right)$ and any slight change in mass beyond this temperature was attributed to $\mathrm{CO}_{2}$ released (Karunadasa et al., 2019) leaving Calcium oxide $(\mathrm{CaO})$. About $17.8 \%$ and $5.2 \%$ of bovine and caprine weight percent respectively remained at the end of the analysis. This showed that the organic content was more in raw caprine bone sample.



Fig. 2. TGA Results of raw bovine and caprine bone samples.

\subsection{Constituent Compounds in the Bones}

The results of XRF analysis of the raw bovine and caprine bone samples are presented in Table 1. As shown in the table, oxides of calcium and phosphorous are the main components in bone samples. The $\mathrm{CaO}$ and phosphoric oxide $\left(\mathrm{P}_{2} \mathrm{O}_{5}\right)$ were 40.36 wt. $\%$ and 31.08 wt. $\%$ in bovine bone and 41.96 wt.\% and 30.90 wt.\% in caprine bone samples respectively. Furthermore, magnesium oxide, strontium oxide, silica, copper oxide, manganese oxide, zinc oxide and silica in minute quantities were found in both bone samples. During the XRF analysis, $26.64 \%$ and $24.89 \%$ of bovine and caprine bone samples respectively were lost on ignition.

Table 1. Oxide composition (XRF analysis) of raw bovine and caprine bone samples

\begin{tabular}{ccccccccccccc}
\hline $\begin{array}{c}\text { Oxide } \\
\text { Composition (\%) }\end{array}$ & $\mathrm{CaO}$ & $\mathrm{P}_{2} \mathrm{O}_{5}$ & $\mathrm{MgO}$ & $\mathrm{SiO}_{2}$ & $\mathrm{MnO}$ & $\mathrm{Fe}_{2} \mathrm{O}_{3}$ & $\mathrm{CuO}$ & $\mathrm{ZnO}$ & $\mathrm{SrO}$ & $\mathrm{BaO}$ & Others & LOI \\
\hline Bovine Bone & 40.36 & 31.08 & 0.43 & 0.18 & 0.078 & 0.19 & 0.016 & 0.019 & 0.15 & - & 0.85 & 26.64 \\
& & & & & & & & & & & & \\
Caprine Bone & 41.96 & 30.91 & 0.50 & 0.20 & 0.018 & - & 0.008 & 0.028 & 0.196 & 0.12 & 1.17 & 24.89 \\
\hline
\end{tabular}




\subsection{Elemental Composition Evaluation of the Bones}

Fig. 3 shows the EDS spectra for bovine and caprine bone powder. The results showed that both bones have similar composition. Calcium $(\mathrm{Ca})$, carbon $(\mathrm{C})$, phosphorus $(\mathrm{P})$ and oxygen $(\mathrm{O})$ were detected to be present in significant amounts in both raw bone samples while sodium $(\mathrm{Na})$, magnesium $(\mathrm{Mg})$, potassium $(\mathrm{K})$, aluminum $(\mathrm{Al})$, silicon $(\mathrm{Si})$ and silver $(\mathrm{Ag})$. Carbon and oxygen showed significant presence in both bone samples, with traces of sulphur (S) and nitrogen $(\mathrm{N})$. These elements are part of the amide functional groups of the collagen (LeónMancilla et al., 2016). The sum of the weight percentage of carbon and oxygen present in caprine $(35.17 \%)$ was more than that of bovine sample $(23.16 \%)$. This indicated that the quantity of collagen in caprine was more than what was present in bovine sample. It is the collagen fibers that provide the ductility and competence of the bone for energy absorbtion, that is, toughness (Viguet-Carrin et al., 2006). The difference in the trace elements composition of bones depend on some biological factors such as nutrition and breed (Rana et al., 2017).

A


Fig. 3. EDS spectra for bovine (A) and caprine (B) bone powder.

\subsection{Functional Groups Present in the Bones}

The FTIR spectra are a combination of that of HAP and collagen, which are the major constituents of raw bones. On the average, bone samples consist of $\sim 60 \%$ inorganic component (HAP), 30\% organic component and 10\% water (Feng 2009). The spectra showed the presence 
of Phosphate $\left(\mathrm{PO}_{4}{ }^{3-}\right)$, Carbonate $\left(\mathrm{CO}_{3}{ }^{2-}\right)$ absorbed water, Amide I and II in both raw samples. The $\mathrm{PO}_{4}{ }^{3-}$ stretching bands in bovine and caprine bone samples appear at wavelength 1018 and $1010 \mathrm{~cm}^{-1}$ respectively (Malla et al., 2020). The characteristic bands for $\mathrm{CO}_{3}{ }^{2-}$ were assigned at 1446, 1409, $872 \mathrm{~cm}^{-1}$ for both bovine and caprine samples. The absorbed water in bovine sample appears in bands 2922 and $3276 \mathrm{~cm}^{-1}$ and 2851, 2922 and $3284 \mathrm{~cm}^{-1}$ for caprine sample (Rana et al., 2017). Also, the Amide I and Amide II bands were 1640 and $1543 \mathrm{~cm}^{-1}$ in bovine, and 1636 and $1543 \mathrm{~cm}^{-1}$ in caprine sample respectively, the Amide peaks could be attributed to the presence of protein (Collagen) macromolecules in the raw bones (Al-Sokanee et al., 2009, Bano et al., 2017). The hydroxyl $\left(\mathrm{OH}^{-}\right)$band $\left(3568 \mathrm{~cm}^{-1}\right)$ was absent in both samples; this may be attributed to the overlapping of impurity bands over the $\mathrm{OH}^{-}$band (Malla et al., 2020). Some of the functional groups bands in the two bone samples appeared in the same wavelength while others were in very close wavelength, Table 2. Contrarily, there was variation in the transmittance percentage especially in the collagen band because of difference in the quantity of the organic substances present in each of them. This reflected that caprine sample contains more of organic substance as the transmittance percentage was lower than that of bovine at collagen band. This is in agreement with the spectra reported by Ramesh et al., (2018), also with the EDS result. The positions and intensities of the respective absorption bands can be influenced by changes in the molecule's environment of the samples (Rana et al., 2017).

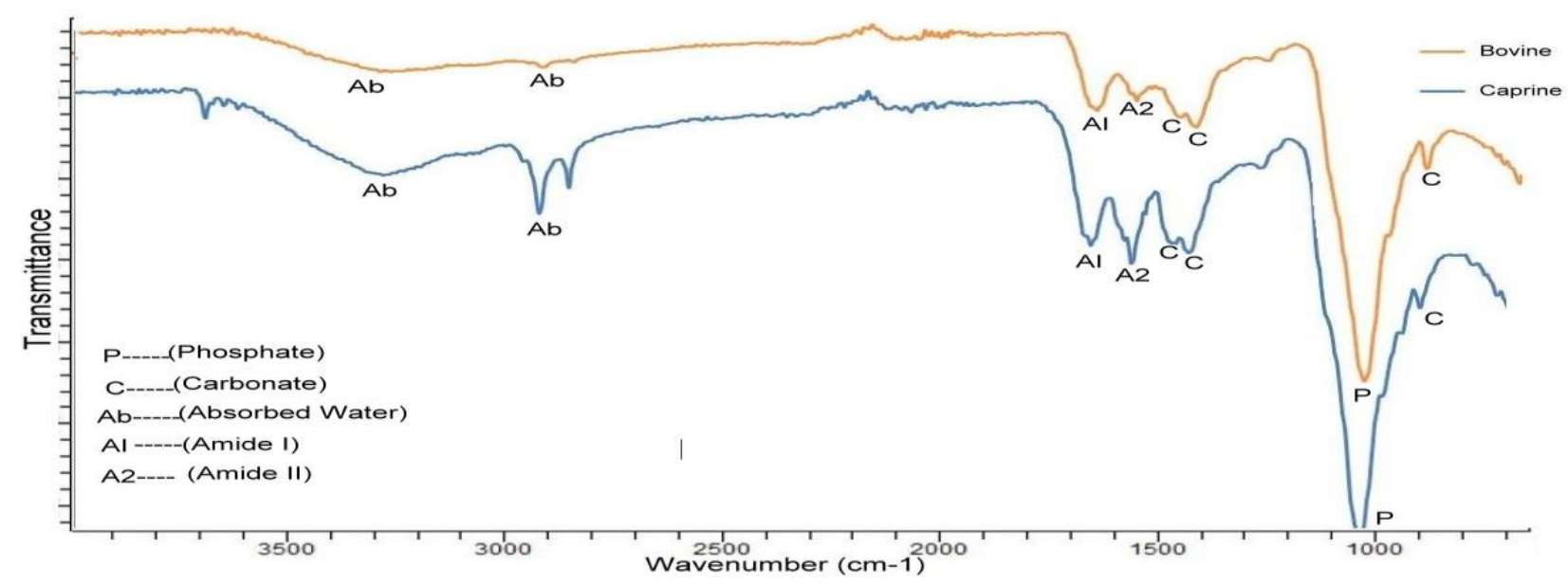

Fig. 4. FTIR spectrum of raw Bovine and Caprine Bone. 
Table 2. FTIR Peaks of bovine and caprine bone samples.

\begin{tabular}{|c|c|c|c|c|c|}
\hline $\begin{array}{l}\text { Functional } \\
\text { Groups }\end{array}$ & $\begin{array}{l}\text { Bovine } \\
\text { Wavelength } \\
\left(\mathbf{c m}^{-1}\right)\end{array}$ & $\begin{array}{l}\text { Bovine } \\
\text { Transmittance } \\
(\%)\end{array}$ & $\begin{array}{l}\text { Caprine } \\
\text { Wavelength } \\
\left(\mathrm{cm}^{-1}\right)\end{array}$ & $\begin{array}{l}\text { Caprine } \\
\text { Transmittance } \\
(\%)\end{array}$ & Reference \\
\hline $\begin{array}{l}\text { Phosphate } \\
\left(\mathrm{PO}_{4}\right)\end{array}$ & 1018 & 69.8 & 1010 & 63.2 & (Malla et al., 2020) \\
\hline $\begin{array}{l}\text { Carbonate } \\
\left(\mathrm{CO}_{3}\right)\end{array}$ & $\begin{array}{ll}872, & 1409, \\
1446 & \end{array}$ & $\begin{array}{ll}86.88, & 90.19, \\
90.99 & \end{array}$ & $872,1409,1446$ & $\begin{array}{l}80.65, \quad 84.87, \\
85.62\end{array}$ & (Malla et al., 2020) \\
\hline $\begin{array}{l}\text { Absorbed } \\
\text { Water }\end{array}$ & 2922,3276 & $95.02,94.66$ & 2922,3284 & $88.22,90.86$ & (Rana et al., 2017) \\
\hline Amide I & 1640 & 91.6 & 1636 & 85.46 & (Bano et al., 2017) \\
\hline Amide II & 1543 & 92.33 & 1543 & 84.1 & $\begin{array}{l}\text { (Al-Sokanee et al., } \\
\text { 2009; Seshadri et al., } \\
\text { 2014) }\end{array}$ \\
\hline
\end{tabular}

\subsection{Crystallographic Phases in the Bones}

Fig. 5 shows the X-ray difraction patterns of raw bovine and caprine bone with HAP and collagen peaks. The XRD parameters of the two bone samples showed they have identical phases present. They reflect some of the characteristic peaks correspond to HAP (Piga et al., 2013). Also, the characteristic peaks of collagen were obtained as weak diffraction peak around $5^{\circ}$ in both samples and a broad hump at around $22^{\circ}$ more noticeable in caprine sample indicating that the presence of amorphous collagen. The weak diffraction peak angle was slightly different from $8^{\circ}$ that was obtained by Sun et al., (2018), also Bak et al., (2018) had reported that the broad hump could also appear around 16-25. The major HAP peak (211) of the XRD graphs for bovine and caprine appear at angle and with intensity $31.92^{\circ}$ and $609,32.02^{\circ}$ and 573 respectively. As revealed by Angeles Blanco (2018), the height of the highest diffraction peak is related to the amount of crystalline material in the sample. According to the peak intensity, this implied that caprine sample has less crystalline HAP phase which indicates more amorphous collagen than the bovine sample. 


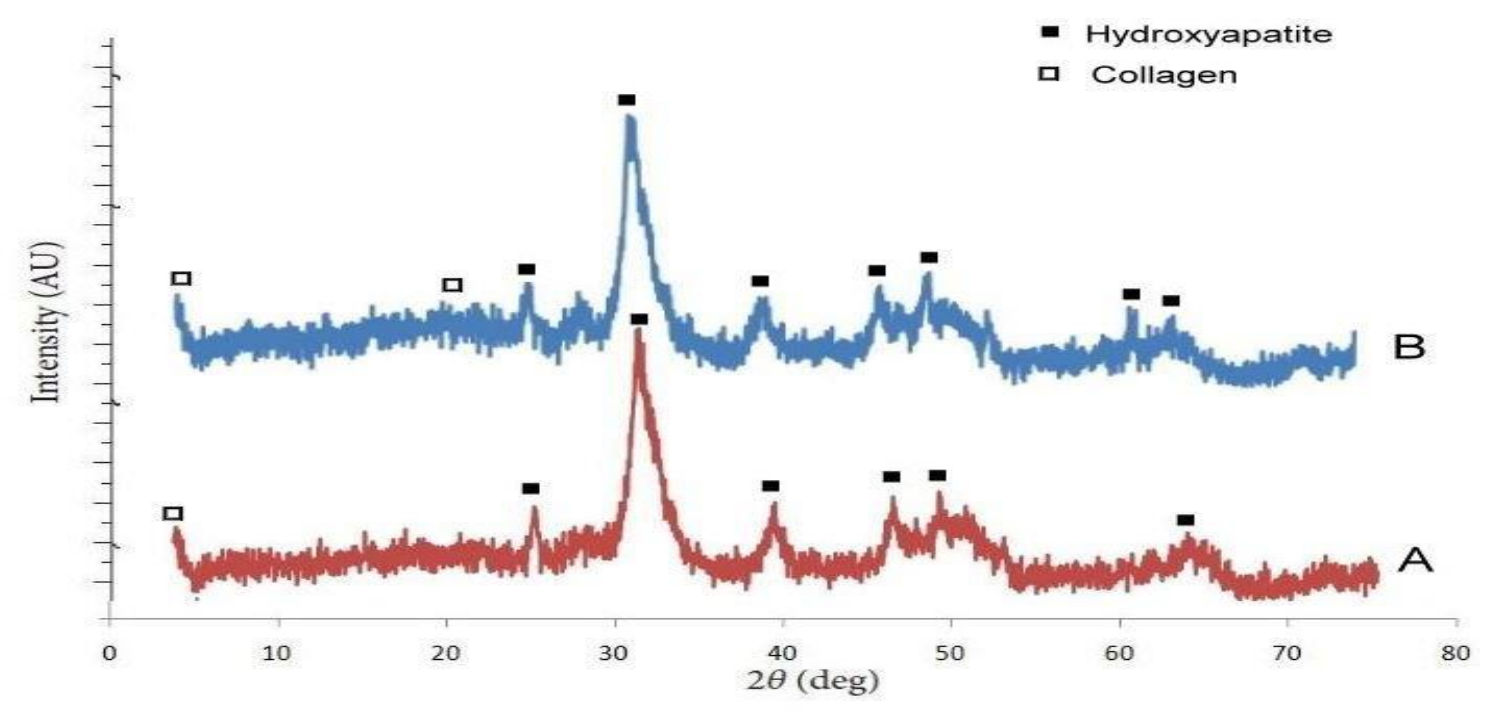

Fig. 5. X-Ray Diffraction (XRD) pattern of raw (A) bovine bone and (B) caprine bone.

\subsection{Morphological Assessments of the Bones}

Fig. $6 \mathrm{~A}$ and $\mathrm{B}$ show the SEM images of bovine and caprine samples respectively. The micrographs show that both bone particles have irregular shapes and non-uniform sizes. Using the scale bar on the SEM images, most of the particles' length were less than $100 \mu \mathrm{m}$ in both samples. The bovine sample seems to have needle-like shape while caprine's was pebble-like. The particles size of caprine sample appeared to be coarser than that of bovine. This might be as a result of caprine bone having more collagen which means more toughness as stated earlier and consequently, more resistance to milling. On visual examination of the SEM, the bovine sample particles surface appeared rougher than that of caprine bone samples. The particle size, shape and surface roughness tend to have effect on the properties of the particles. The particle size plays an important role in the drug release profile of the particles (Sasikuma, 2013). Particle shape may also play roles in physical properties like flowability, compactibility, permeability, bulk and tap density (Olson, 2011). The surface roughness influences the drug carrying capacity and it is believed to critically affect drug carrier interactions (Tan et al., 2015). However, the size, shape and the surface roughness are likely to change when the bovine and caprine bone particles are exposed to calcination. 


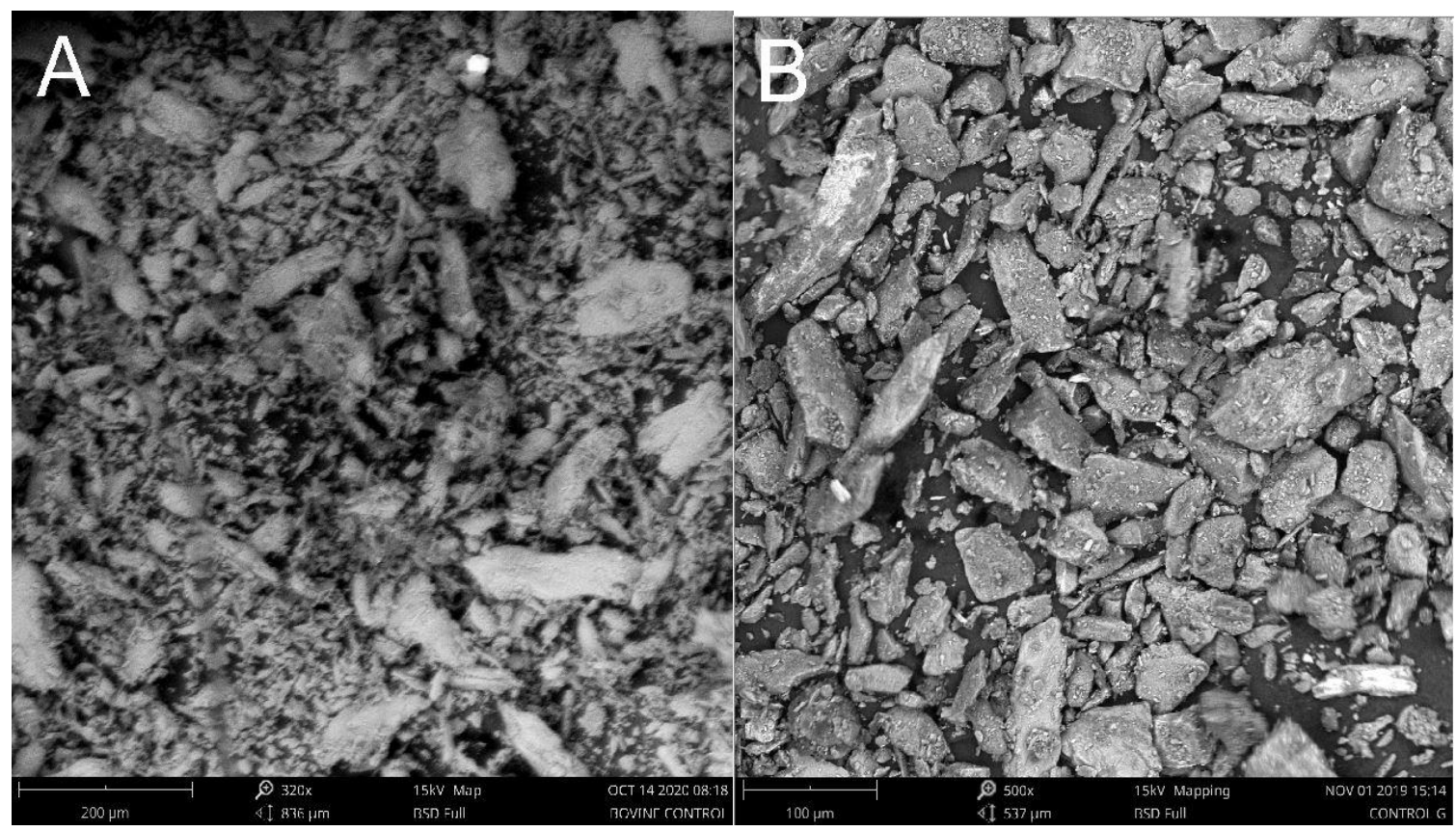

Fig. 6. The SEM Morphology of raw powder of (A) bovine bone (B) caprine bone.

\section{CONCLUSIONS}

The present study has shown the compositions of the organic and inorganic phases of the raw bovine and caprine bone samples as revealed by EDS and XRF. FTIR spectra and TGA reveal that caprine bone holds more collagen content which is equally useful in some biomedical applications than bovine bone. The XRD showed that both bones have almost identical phases present in them. Although, there was no much difference in thermo-chemical properties of bovine and caprine bone raw samples, but these properties are likely to change when they are subjected to further extraction and purification processes to get the HAP and the collagen out of the bone samples for biomedical and orthopaedics applications.

\section{REFERENCES}

Al-Sokanee, Z. N., Toabi, A. A. H., Al-assadi, M. J. and Alassadi, E. A. S. (2009). The Drug Release Study of Ceftriaxone from Porous Hydroxyapatite Scaffolds. AAPS PharmSciTech, 10(3), DOI: 10.1208/s12249-009-92657.

Angeles Blanco, M., Monte, C.,Campano, C., Balea, A., Merayo, N. and Negro, C. (2018). Handbook of Nanomaterials for Industrial Applications. Amsterdam, Elsevier,pp 74126.doi.org/10.1016/B978-0-12-813351-4.00005-5.

Bak, S.Y., Lee, S. W., Choi, C., and Kim, H. W. (2018). Assessment of the Influence of Acetic Acid Residue on Type I Collagen during Isolation and Characterization. Article in Materials, DOI: $10.3390 / \mathrm{ma} 111225180$ 
Bano, N., Jikan, S. S., Basri, H., Adzila, S. S., Bakar, A. and Nuhu, A. H. (2017). NaturalHydroxyapatite Extracted From Bovine Bone. Journal of Science and Technology, $9(2), 22-28$.

Feng X. (2009). Chemical and Biochemical Basis of Cell-Bone Matrix Interactionin Health and Disease. Curr Chem Biol; 3(2), 189-196. doi:10.2174/187231309788166398

Hirata, A., Maruyama, Y., Onishi, K., Hayashi, A., Saze, M. and Okada, E. (2008). A Vascularized Artificial Bone Graft Using the Periosteal Flap and Porous Hydroxyapatite: Basic Research and Preliminary Clinical Application. Wound Repair and Regeneration, 12(1).

Kano, S., Yamazaki, A., Otsuka, R., Ohgaki, M., Akao, M., and Aoki,H. (1994). Application of Hydroxyapatite-Sol as Drug Carrier. Bio-Medical Materials and Engineering, 4(4), 283.

Karunadasa, K. S. P., Manoratne, C.H., Pitawala, H.M. and Rajapakse, R.M.G. (2019).Thermal Decomposition of Calcium Carbonate (Calcite Polymorph) as Examined by In-Situ HighTemperature X-Ray Powder Diffraction. Journal of Physics and Chemistry of Solids, 134, 2128, ISSN 0022-3697, https://doi.org/10.1016/j.jpcs.2019.05.023

León-Mancilla B.H., Araiza-Téllez M.A., Flores-Flores J.O. and Pi na-Barba M.C. (2016). Physico-chemical Characterization of Collagen Scaffolds for Tissue Engineering, Journal of Applied Research and Technology, 14, 77-85.

Malla, K. P., Regmi, S., Nepal, A., Bhattarai, S., Yadav, R. J., Sakurai, S. and Adhikari, R.(2020). Extraction and Characterization of Novel Natural Hydroxyapatite Bioceramicby Thermal Decomposition of Waste Ostrich Bone. Hindawi International Journal of Biomaterial, 10 pages. https://doi.org/10.1155/2020/1690178

Manalu, J. L. Soegijono, B. and Indrani, D. J. (2015). Characterization of Hydroxyapatite Derived From Bovine Bone. Asian Journal of Applied Sciences, 3(04), (ISSN: 2321 - 0893).

Mkukuma, L. D., Skakle, J. M. S., Gibson, I. R., Imrie, C. T., Aspden, R. M. and Hukins, D. W. L. (2004). Effect of the Proportion of Organic Material in Bone on Thermal Decomposition of Bone Mineral. Calcif Tissue Int, 75, 321-328. DOI: 10.1007/s00223-004$0199-5$

MohdPu'ad, N.A.S., Koshy, P., Abdullah, H.Z., Idris, M.I. and Lee, T.C. (2019). Syntheses of Hydroxyapatite from Natural Sources. Heliyon, 5. E01588

Nair, M. B., Babu, S. S., Varma, H. K.,and John, A. (2008). A Triphasic Ceramic-Coated Porous Hydroxyapatite for Tissue Engineering Application. Acta Biomaterialia, 4(1), 173-181. Olson, E. (2011). Particle Shape Factors and Their Use in Image Analysis Part II: Practical Applications. GXP Autumn, 15(4). 
Omole, D. O. and Ogbiye, A. S. (2013). An Evaluation of Slaughterhouse Wastes in SouthWest Nigeria. American Journal of Environmental Protection, 2(3), 85-89. DOI:10.11648/j.ajep.20130203.12.

Piga, G., Solinas, G., Thompson, T. J. U., Brunetti, A., Malgosa, A. and Enzo, S. (2013). Is XRay Diffraction Able to Distinguish Between Animal And Human Bones? Journal of Archaeological Science, 40, 778-785.

Ramesh, S., Looa, Z.Z., Tana, C.Y., Chewb, W.J. K., Chinga, Y.C., Tarlochanc, F., Chandrand, H., Krishnasamye, S., Bangf, L.T and Sarhan, A. A. D. (2018).Characterization of Biogenic Hydroxyapatite Derived From Animal Bones for Biomedical Applications. Ceramics International, 44, 10525-10530.

Rana, M., Akhtar, N., Rahman, S., Jamil, H. and Saduzzaman S. M. (2017). 'Extraction of Hydroxyapatite from Bovine and Human Cortical Bone by Thermal Decomposition and Effect of Gamma Radiation' A Comparative Study. Int J Complement Alt Med 8(3), 00263. DOI:10.15406/ijcam.2017.08.00263

Reichert, J. and Binner, J. G. P. (1996). An Evaluation of Hydroxyapatite-Based Filters for Removal of Heavy Metal Ions from Aqueous Solutions. Journal of Materials Science, 31(5), $1231-1241$.

Salman, S., Soundararajan, S., Safina, G., Satoh, I., and Danielsson, B. (2008). Hydroxyapatite as a Novel Reversible in Situ Adsorption Matrix for Enzyme Thermistor-Based FIA. Talanta, 77(2), 490-493.

Sasikumar, S. (2013.) Effect of Particle Size of Calcium Phosphate Based Bioceramic Drug Delivery Carrier on The Release Kinetics of Ciprooxacinhydrochloride: An In Vitro Study. Mater.Sci., 7(3), 261.

Seshadri, S., Thotapalli, S. and Kumar, B. S. (2014). Synthesis and Characterization of a Novel Bone Graft Material Using Biphasic Calcium Phosphate Casein Chitosan with the Extracts of Coriandrum Sativum. International Journal of Pharmacy and Pharmaceutical Sciences, 6(5).

Staffa, G., Nataloni, A., Compagnone, C. and Servadei, F. (2007). Custom Made Cranioplasty Prostheses in Porous Hydroxy-Apatite Using 3D Design Techniques: 7 Years experience in 25 patients. Acta Neurochirurgica, 149(2), 161-170.

Sun, T., Zhu, Y. and Chen F. (2018). Hydroxyapatite Nanowire/Collagen Elastic Porous Nanocomposite and its Enhanced Performance in Bone Defect Repair, RSC Adv, 8, 26218 Tan, B. M. J., Liew, C. V., Chan, L. W. Heng, P. W. S.(2015). Particle Surface Roughness Its Characterisation and Impact on Dry Powder Inhaler Performance. https://doi.org/10.1002/9781118799536.ch9. 
Tang, P. F., Li G., Wang J. F., Zheng Q. J. and Wang, Y. (2009). Development, Characterization, and Validation of Porous Carbonated Hydroxyapatite Bone Cement. Journal of Biomedical Materials Research. Part B, Applied Biomaterials, 90, 886-893.

Venkatesan, J. and Kim, S. (2013). Hydroxyapatite From Marine Fish Bone: Isolation andCharacterization Techniques. DOI: 10.1201/b14723-4.

Viguet-Carrin, S., Garnero, P. and Delmas, P.D. (2006). The Role of Collagen in Bone Strength. Osteoporos Int, 17, 319-336. doi.org/10.1007/s00198-005-2035-9. 